\title{
Compounds from Deep-Sea Bubblegum Corals, Paragorgia arborea, Elicit Anti-Predation Behavior in Fish
}

\author{
Larissa M. Bright-Diaz ${ }^{1}$, Kevin B. Strychar ${ }^{*}, 1$ and Thomas C. Shirley ${ }^{1,2}$ \\ ${ }^{I}$ Department of Life Sciences, Texas A\&M University, Corpus Christi, Corpus Christi, Texas, 78412, USA \\ ${ }^{2}$ Harte Research Institute for Gulf of Mexico Studies, Texas A\&M University, Corpus Christi, Corpus Christi, Texas, \\ 78412, USA
}

\begin{abstract}
Bubble-gum corals (Paragorgia spp.) appear to lack predators common to many other deep-sea corals. The aim of this study was to determine whether compounds from red and white colored bubble-gum coral Paragorgia arborea (Linnaeus, 1758) from different geographical locations inhibit predation or elicit different behavioral responses. We extracted secondary metabolites from red and white colonies of $P$. arborea, incorporating different concentrations of the compounds into feeding pellets, and offered these to pinfish Lagodon rhomboides (Linnaeus, 1766) in behavioral feeding assays. Red-colored $P$. arborea produced a lipophilic compound which at high concentrations stimulated defensive responses, however, lipophilic compounds from white coral colonies did not produce significant defensive behavioral responses by fish. Water-soluble and extracted sclerites elicited no behavioral effects from L. rhomboides.
\end{abstract}

Keywords: Defensive compounds, deep-water coral, feeding assays, secondary metabolites.

\section{INTRODUCTION}

Deep-sea corals (DSCs) are widespread and can be found in every ocean to $5800 \mathrm{~m}$ depth [1]. Like shallow-water scleractinian corals, DSCs provide habitat and food for many marine organisms [2, 3]. Mortensen and Buhl-Mortensen [4], for example, identified 1,264 organisms in 13 Paragorgia colonies. Deep-sea corals are suspension-feeders that contain calcium carbonate sclerites or spicules within their tissues, and may have symbionts, although the purpose of symbionts remains largely unknown since these corals exist in the aphotic zone [5]. Moreover, DSCs have extremely slow growth rates so individual colonies may be hundreds or even thousands of years old [6].

A bubblegum coral, Paragorgia (Paragorgiidae; Octocorallia) is a cold-water gorgonian genus that has a broad global distribution and is eurybathic from depths of meters to kilometers [7]. Most species are fan-shaped and concave, with thick branches, reaching in excess of $2 \mathrm{~m}$ in height (Fig. 1). Paragorgiids are unusual in that they lack a corneous or calcareous axial skeleton typical of most branching gorgonians [8]. The massive structure is instead supported by calcitic sclerites [9]. They exhibit a wide color variation including salmon-pink, black, brown, pumpkinorange, yellow, red and white although the latter two are by far the most commonly observed morphs [10]. Despite possessing a wide color variation, the color morphs co-occur geographically within the same temperature gradients and as a consequence, it is not known what role particular colors may play in DSCs. The genus Paragorgia, however, appears to have a relative absence of coral predators (T. Shirley, J.

*Address correspondence to this author at the Department of Life Sciences, Texas A\&M University - Corpus Christi, Corpus Christi, Texas, 78412, USA; Tel: 361-825-5883; Fax: 361-825-2025;

E-mail: kevin.strychar@tamucc.edu
Sanchez, personal observations). Hence, we speculated that Paragorgia species are somehow defended against predators but not beneficial species using two different defense mechanisms: (1) physical, by producing hard, spiny scleridial particles that make the coral unpalatable to predators: and, (2) chemical, by producing chemical compounds that may deter fish from consuming the corals. Although chemical compounds have been isolated from DSCs, their ecological role, i.e., anti-predation, has not been examined [11, 12]. Rice [13] and Rozadowski [14] suggested that chemical communication in the deep-sea may be important in ecological relationships. In such light-deficient environments, inter- and intra-species communication is believed to primarily occur via chemoreception [15].

Three distinct xeniolide diterpenoids were found within tissues of $P$. arborea collected near the Crozet Islands of the Southern Indian Ocean [11]. Two of these compounds, coraxeniolide-C and coraxeniolide-B, were identical with those from a Corallium sp. of Hawaii, which is related to the genus Paragorgia [8]. One of the compounds, arboxeniolide-1 was novel in nature although it had been synthesized previously as coraxeniolide-D' [11]. These xeniolide diterpenoids are crystalline, lipophilic compounds similar to those contained within Dictyotales brown algae $[16,17]$. It is unclear whether $P$. arborea produced the compounds themselves or ingested them during suspension feeding. Paragorgia arborea from the Kurile Islands near Japan and Russia had a different xeniolide diterpenoid [12], supporting speculation that these corals may be ingesting rather than producing such compounds. If the corals were producing compounds, the compounds should be relatively similar for all species, despite geographic region or depth. Three novel steroids (parathiosteroids A-C) were found in an unidentified Paragorgia sp. collected near Madagascar [18]. The steroid compounds had cytotoxic effects on three human tumor cell lines (colon HT-29, lung A-549, and breast MDA- 


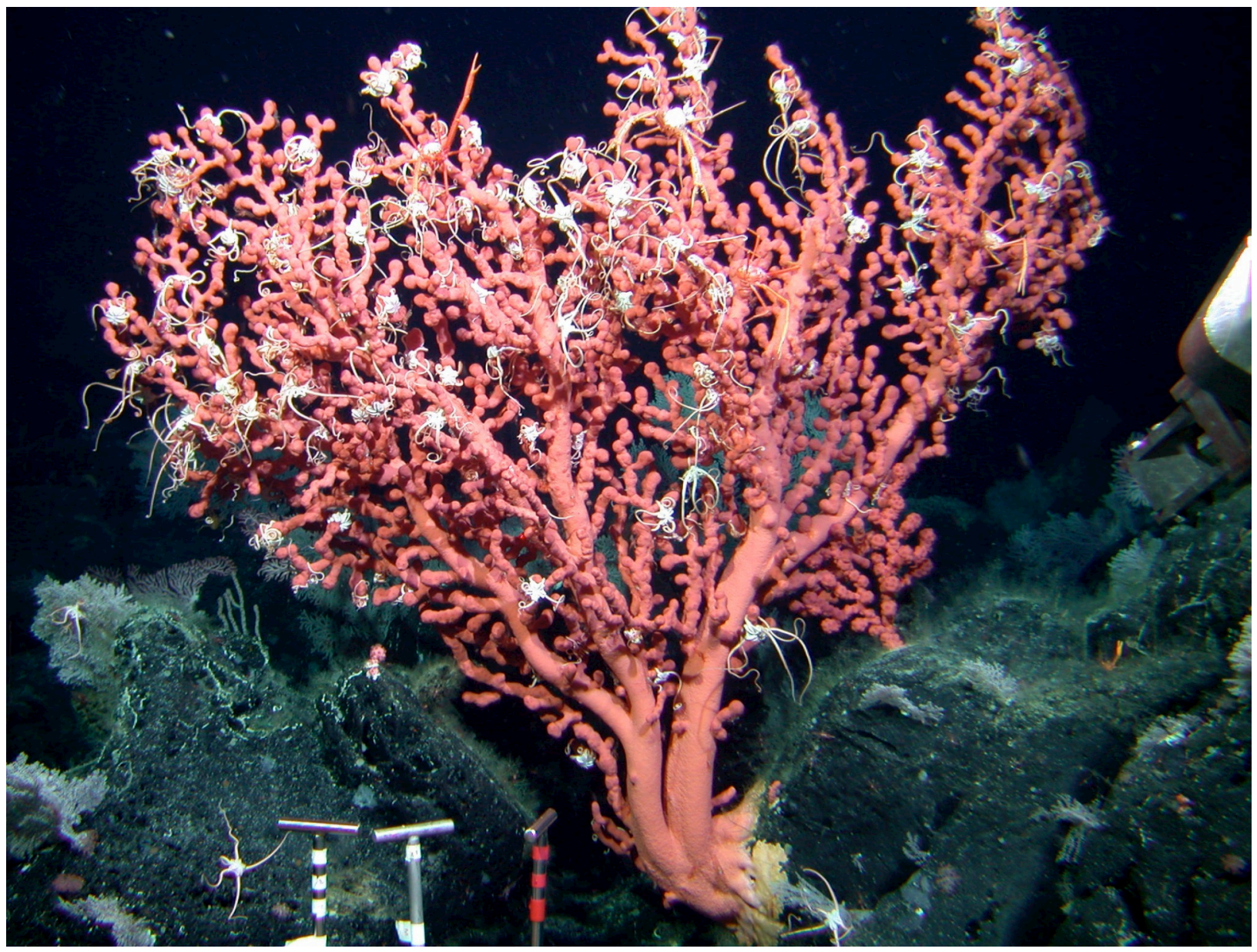

Fig. (1). Paragorgia arborea in situ on Warwick Seamount, July 15, 2002, Alvin Dive 3806 at $780 \mathrm{~m}$ depth. The specimen was approximately $2.0 \mathrm{~m}$ in height and width. Image courtesy of NOAA Office of Ocean Exploration, WHOI, The Alvin Group, and the 2002 Gulf of Alaska Seamounts Expedition Science Party. Tissues collected from this specimen were used in the experiment.

MB-231) [18]. In all of these studies the isolated compounds were lipophilic in nature; however, in some species the compounds identified were terpenes versus others which were steroids. At low concentrations, terpenes are used in "signaling" and in marine species are important defensive molecules, however, at high concentrations, they can be toxic. Steroids, considered modified triterpenes, are important structural components of cell membranes and are involved in hormonal roles in higher organisms. In tropical shallow-water corals, terpenes and steroids are common and function as anti-predatory defenses, however, many corals are still consumed by corallivorous fishes (e.g. parrot fish, butterfly fish). Although the presence of terpenes and steroids have been isolated and identified in DSCs, their role remains unknown.

\section{Objectives}

The objectives of this study were to isolate and examine the defensive properties of compounds contained within $P$. arborea from different geographic regions and of different color morphologies. Although coloration should not play a role in deep water ecology because there is no light [19], deep sea organisms retain the genetic tendency to produce bright colors [20]. We hypothesize: (1) Paragorgia arborea from various geographic regions will elicit different anti- predatory responses in fish; (2) fish will display more avoidance to brighter colored $P$. arborea deep-sea coral species; (3) fish will display more avoidance to lipophilic DSC compounds than to any other treatment; and, (4) sclerites of $P$. arborea serve a role in predator avoidance.

\section{MATERIALS AND METHODS}

\section{Specimens}

Coral colonies of Paragorgia arborea were collected from two different geographical locations. One location was near Cape Moffet, Adak Island (Aleutians), Alaska, in the North Pacific Ocean $\left(51^{\circ} 57.728^{\prime}\right.$ N, 176 $50.072^{\prime}$ W). Deepsea coral samples were collected by submersible or remotely operated vehicle (ROV) at $145 \mathrm{~m}$ depth and either dried or preserved at $-61^{\circ} \mathrm{C}$. Other samples of red and white-colored $P$. arborea specimens were collected by ROV near Nova Scotia, Canada, in the North Atlantic Ocean and upon collection, were immediately frozen. Freezing is the preferred method for chemical extractions [21] although dried samples are considered acceptable, albeit less-effective as chemical compounds may be volatile and diminish in concentration over time [22].

Collecting and maintaining live deep-sea predators is problematic because of differences in pressure and tempera- 
ture. As a result, we used pinfish Lagodon rhomboides as a test species. Other research supports the use of generalist predators [23] when natural predators are unavailable, although the research must be conducted over the course of several days to allow a predator to "learn" a response to a compound that they were previously unexposed to [24]. Additionally, generalist fishes, unlike specialist predators, would be unlikely to have evolved ways to circumvent chemical defenses [25]. Pinfish are hardy, have a broad diet range [26-28], are more readily available, are easy to handle and transport, and will readily consume most foods [29]. Pinfish were collected with seine, cast net, and bait traps at high salinity sites near our laboratory.

\section{Extractions of Crude Extracts and Calcitic Sclerites}

Chemical compounds were extracted from DSC tissue following various procedures described by Pawlik and Fenical [26], Pawlik et al. [25], Puglisi et al. [30], Lopanik et al. [23], Epifanio et al. [31], and Ritson-Williams and Paul [19]. Prior to extractions, the volume of each coral specimen was determined by water displacement. This information was used to calculate the natural volumetric concentration (NVC) of extract per tissue sample [31]. To extract the chemical compounds, coral tissues were processed through four phases.

\section{Phase I}

Coral tissues were first macerated using a mortar and pestle and then added to labeled Corning ${ }^{\circ}$ polypropylene scintillation vials in which deionized (DI) water was added to a total volume of $50 \mathrm{ml}$; a control was prepared by adding $50 \mathrm{ml}$ of DI water to a clean, empty vial. Capped tubes containing macerated coral specimens and a control vial were then inverted, agitated repeatedly, sonicated with a Branson 3510 sonicator for $20 \mathrm{~min}$, and incubated for $24 \mathrm{~h}$ at $\sim 4^{\circ} \mathrm{C}$ to allow the compounds to leach into solution. Following incubation, the slurry was then centrifuged with a Beckman Coulter Allegra 25R at $1200 \times g$ for $20 \mathrm{~min}$. The supernatant was decanted and lyophilized to dryness. The volume and weight of these extracts were determined and the extracts were stored at $4^{\circ} \mathrm{C}$ in polypropylene scintillation vials until needed.

\section{Phase II}

The remaining tissues were weighed and resuspended in a 1:1 mixture of dichloromethane (DCM) and methanol $\left(\mathrm{CH}_{3} \mathrm{OH}\right)$ to a total volume of $50 \mathrm{ml}$; a control consisted of an empty vial with equal ratios of $25 \mathrm{ml}$ of DCM and $25 \mathrm{ml}$ methanol. Capped vials were inverted and agitated and the method described previously was repeated. However, in this step involving DCM and methanol, the supernatant was rotary evaporated using a Büchi Rotavapor R200 with a heating bath at $30^{\circ} \mathrm{C}$ until only a small proportion of the methanol extraction remained. Extractions were then evaporated to dryness with a vacuum oven at room temperature and 10-20 psi.

\section{Phase III}

Remaining coral tissues were extracted again, but with pure methanol added to a total volume of $50 \mathrm{ml}$; extraction (i.e., leaching) and lyophilization followed the methods described above. Methanol and DCM:methanol extractions were then combined for each lipophilic feed assay, and maintained at $\sim 4^{\circ} \mathrm{C}$ until needed.

\section{Phase IV}

As a final step, tubes containing any remaining coral tissues were filled with $6 \%$ sodium hypochlorite (bleach). Bleach dissolves organic tissues $(\sim 4.5 \mathrm{hr})$ leaving behind any calcitic sclerites. The bleach supernatant was decanted and disposed of and fresh bleach was added. This process was repeated twice to ensure complete dissolution of the organic coral tissues. After the final treatment, the bleach was decanted and the pellet was rinsed three times in DI water. The pellet was then soaked in $1 \mathrm{M}$ sodium thiosulfate $\left(\mathrm{Na}_{2} \mathrm{~S}_{2} \mathrm{O}_{3}\right)$ for $15 \mathrm{~min}$. to neutralize any residual bleach, followed by rinsing thrice with DI water, drying by heat at $105^{\circ} \mathrm{C}$ for $1 \mathrm{~h}$, and finally determination of weight. A control was also produced and put through the same process minus the addition of coral tissues. Sclerites were placed in polypropylene scintillation vials at $4^{\circ} \mathrm{C}$ until needed.

\section{Food Treatments}

Overall, seven types of extractions used in feeding assays were prepared from the DSC samples, and included watersoluble extracts of $50 \%, 100 \%$ and $200 \%$ of the $\mathrm{NVC}$, lipophilic extracts at $50 \%, 100 \%$, and $200 \%$ of the NVC, and a sclerite extraction at $100 \% \mathrm{NVC} ; 100 \% \mathrm{NVC}$ extraction is representative of a whole colony and each colony used, being of comparable in weight. Water-soluble extractions were taken to widen the scope of possible ecological consequences that may contribute to the defensive mechanisms used by DSCs [23]. Lipophilic extractions were collected because these compounds (diterpenoids and steroids), although having been previously isolated in Paragorgia spp., have never been tested to determine their ecological significance $[11,12,16,18]$. Lastly, sclerite extractions were also used because these may inhibit fish predation [30]. Different concentrations of each type of extract were used because the concentration of defensive compounds may vary with depth, geographic location, or color morph (i.e., red $v s$. white) [22]. Overall, twelve different food treatments were prepared and analyzed (Table 1).

\section{Preparation of Food Pellets}

The preparation of food pellets containing crude extracts used for feeding assays were based on the methods described by Pawlik et al. [25]. These authors prepared feeding pellets without the use of heat, which may cause volatile compounds to evaporate $[32,33]$. In our study, a large batch of $0.25 \mathrm{M} \mathrm{CaCl}_{2}$ solution was first produced. Then, ratios of $0.4 \mathrm{~g}$ freeze-dried macerated brine shrimp and $0.3 \mathrm{~g}$ sodium alginate were added for every $10 \mathrm{ml}$ of food produced. For example, with our first extraction $(50 \% \mathrm{NVC}), 0.4 \mathrm{~g}$ of the brine shrimp and $0.3 \mathrm{~g}$ of the alginate were combined with the extract and DI water to $10 \mathrm{ml}$ (final volume). Once the ingredients were mixed, they were homogenized vigorously and loaded into a $50 \mathrm{ml}$ tipless syringe. The syringe tip was submerged into separate tubs for each treatment of the 0.25 $\mathrm{M} \mathrm{CaCl}_{2}$ solution and emptied so that a long, spaghetti-like strand remained. A few minutes were allowed for the strand to harden, and then the hardened strand was rinsed three times with seawater from the tanks and cut into $2 \mathrm{~mm}$ long 
pellets with a razor. Food treatments were frozen in polypropylene scintillation vials until $24 \mathrm{~h}$ before use, when they were moved to the refrigerator at $4^{\circ} \mathrm{C}$.

Table 1. Different Food Treatments Prepared Using Crude Extracts Isolated from Red and White Bubble-Gum Coral (Paragorgia arborea)

\begin{tabular}{|c|}
\hline Food Treatment \\
\hline \hline $50 \%$ NVC lipophilic, red, Atlantic \\
\hline $100 \%$ NVC lipophilic, red, Atlantic \\
\hline $200 \%$ NVC lipophilic, red, Atlantic \\
\hline $50 \%$ NVC water soluble, red, Atlantic \\
\hline $100 \%$ NVC water soluble, red, Atlantic \\
\hline $200 \%$ NVC water soluble, red, Atlantic \\
\hline $100 \%$ NVC sclerites, red, Atlantic \\
\hline $200 \%$ NVC lipophilic, white, Atlantic \\
\hline $200 \%$ NVC lipophilic, red, Pacific \\
\hline Control lipophilic \\
\hline Control water soluble \\
\hline Control sclerites \\
\hline
\end{tabular}

\section{Seawater System and Feeding Assays}

The seawater system used in this study was composed of 18 connected tanks with recirculating treated seawater (Fig. 2). The system was equipped with a UV disinfection unit and a pressurized sand filter. Water was tested bi-weekly for temperature $\left({ }^{\circ} \mathrm{C}\right)$, salinity, dissolved oxygen, ammonia $\left(\mathrm{NH}_{4}{ }^{+}\right)$, nitrates $\left(\mathrm{NO}_{3}{ }^{-}\right)$, and nitrites $\left(\mathrm{NO}_{2}\right)$ with an YSI ProPlus meter.

Feeding assays were based on protocols used by Pawlik and Fenical [26], Pawlik et al. [25], Puglisi et al. [30], Lopanik et al. [23], Epifanio et al. [31], and Ritson-Williams and Paul [19]. First, groups of 10 or more pinfish were acclimated in tanks, during which time they were fed control food pellets that resembled treatment food but lacked chemical extracts, and mysis shrimp (Mysidae) ad libidum once per day. Following acclimation (10 days), the standard length (SL) of each pinfish was measured; each individual fish was then randomly placed in one of 18 trial tanks (Fig. 2). Individual pinfish were given an additional three days to acclimate because they were now alone and not with a group of fish. During this period of time, each pinfish was fed six control food pellets. However, pinfish were starved for $24 \mathrm{~h}$ prior to feeding trials. Each tank (Fig. 2) was covered to help reduce stress that may result from the presence of observers. Covered tanks contained a series of dark lenses to simulate video camera lenses and were intended to operate in a manner similar to a bird blind, in which the bird does not

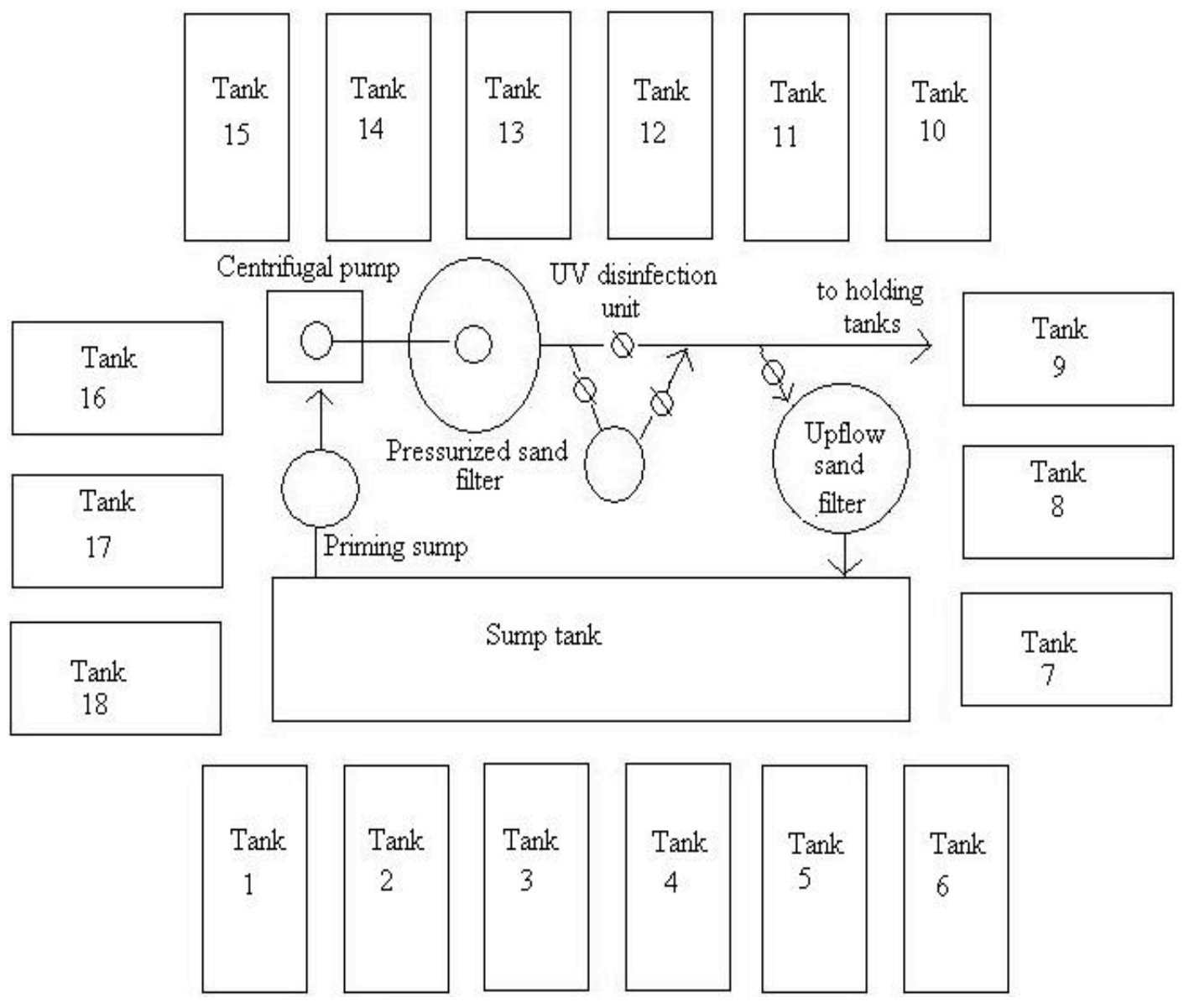

Fig. (2). The seawater system used in this study was composed of 18 connected tanks with recirculating treated seawater. The system was equipped with a UV disinfection unit and a pressurized sand filter. 
notice the observer because holes and patterns in the blind disguise the observers. Feeding trials were conducted over a three-day period. During each trial pinfish were offered different pellets sequentially, however, the particular time of feeding was randomized to prevent/deter a learned response. Food treatments consisted of: (a) a control food pellet with no extract or control treatments but otherwise identical to treatments; (b) the treatment food pellet; and (c) four additional control food pellets such as those used in (a). The experiment was double-blind, meaning that the treatments were coded in such a way that the researcher was unaware of which treatment was being offered to the pinfish, to help reduce bias. All trials were video recorded. The total number of feeding trials was five, hence the total number of fish used was equivalent to 18 fish multiplied by five trials equaling 90 per treatment; 12 different treatments were tested over the duration of the studies (Table $\mathbf{1}$ ).

Behavioral responses of pinfish to experimental treatment feeds were defined based on procedures described by Lee and Meyers [34] and those used in similar feeding assays by Pawlik et al. [25], Kicklighter et al. [33], and Epifanio et al. [31]. If pinfish did not eat at least two of the six pellets offered at any given time, they were considered not hungry and were not considered in future analyses because they were assumed to be affected by laboratory conditions and not responding naturally [25].

Preliminary statistical analyses were conducted with statistical software $\mathrm{R}$ [35] to help determine how many behaviors should be monitored; a size of seven behavioral responses per treatment of food was the minimum number of behaviors required to produce statistically reliable data. Hungry fish were analyzed for responses to food treatments according to:

(a) three or more attempts to ingest treatment food without eventual consumption (deterrent);

(b) treatment food was approached within $10 \mathrm{~cm}$ but ignored (suppressant);

(c) fish ceased movement when treatment food is introduced into tank;

(d) fish did not eat the treatment food but also does not display any defensive behavioral response to it (assumed that fish are not paying attention);

(e) fish ate the treatment food without displaying any defensive behavioral response;

(f) fish swam away when food was introduced into tank (repellent); and

(g) fish ate food and perished or became ill (toxic).

\section{Statistical Analyses}

Data were categorical (nominal) and some treatments had few replicates per assay. Therefore, a chi-square, goodnessof-fit, and similar statistical analyses were not appropriate as the assumption that none of the expected cell counts would be less than one was not met [36]. Instead, a multinomial logistic regression model [37] was used to determine significance between behavioral responses and food treatments. This model is capable of considering all variables except water quality parameters; tests were conducted in $\mathrm{R}$ [35].
Logistic regressions were conducted to determine whether the model fitted the data, and goodness-of-fit and HosmerLemeshow goodness-of-fit tests were used to determine model appropriateness [37].

\section{RESULTS}

\section{Treatments}

Logistic regression analyses used to determine whether the model fit the data resulted in $p<0.001$, indicating that the model was an acceptable fit [37]. Goodness-of-fit and Hosmer-Lemeshow goodness-of-fit tests were run and the model was appropriate $(p=0.979$ and $p=0.585$, respectively) [37]. The final model was found to be of poor predictive power, yet capable of determining which treatments elicited behavioral response in predatory fish.

The majority of hungry fish ate treatments normally and did not respond defensively (i.e., no significant differences; Fig. 3). None of the pinfish responded defensively to the sclerites or water-soluble treatments, the $100 \% \mathrm{NVC}$ sclerite treatment, and the $50 \% \mathrm{NVC}$ lipophilic treatment extracted from the red $P$. arborea colonies collected from the Northern Atlantic Ocean.

However, the $200 \%$ NVC lipophilic food treatment with extracts from red $P$. arborea colonies from the North Atlantic Ocean produced significantly different behavioral response when compared to all other treatments $(z$-score $=$ 2.36, $p=0.018$, multinomial model, program $\mathrm{R}$ ) (Table 2).

Table 2. Results of Multinomial Modeling Analyses. The Baseline to which Other Values were being Compared was Day 1, 100\% NVC Lipophilic Food Treatment, Prepared from Red Paragorgia arborea from the Atlantic Ocean

\begin{tabular}{|c|c|c|}
\hline Variable & z Statistic & $p$-Value \\
\hline Intercept & -1.87 & 0.613 \\
\hline Day 2 & 1.38 & 0.168 \\
\hline Day 3 & 0.58 & 0.561 \\
\hline $\begin{array}{l}50 \% \text { water soluble food treatment, prepared } \\
\text { from red } P \text {. arborea from the Atlantic Ocean }\end{array}$ & 0.42 & 0.672 \\
\hline $\begin{array}{l}100 \% \text { water soluble food treatment, prepared } \\
\text { from red } P \text {. arborea from the Atlantic Ocean }\end{array}$ & -0.10 & 0.920 \\
\hline $\begin{array}{l}200 \% \text { water soluble food treatment, prepared } \\
\text { from red } P \text {. arborea from the Atlantic Ocean }\end{array}$ & 0.22 & 0.828 \\
\hline $\begin{array}{l}200 \% \text { lipophilic food treatment, prepared from } \\
\quad \text { red } P \text {. arborea from the Atlantic Ocean }\end{array}$ & 2.36 & 0.018 \\
\hline $\begin{array}{l}200 \% \text { lipophilic food treatment, prepared from } \\
\text { white } P \text {. arborea from the Atlantic Ocean }\end{array}$ & 1.40 & 0.162 \\
\hline $\begin{array}{l}200 \% \text { lipophilic food treatment, prepared from } \\
\text { red P. arborea from the Pacific Ocean }\end{array}$ & 1.21 & 0.227 \\
\hline Control lipophilic food treatment & 1.25 & 0.211 \\
\hline Pinfish standard length (SL) & -0.86 & 0.387 \\
\hline
\end{tabular}

In addition, pinfish had significantly greater behavioral responses (i.e., avoidance) to food treatments prepared from 


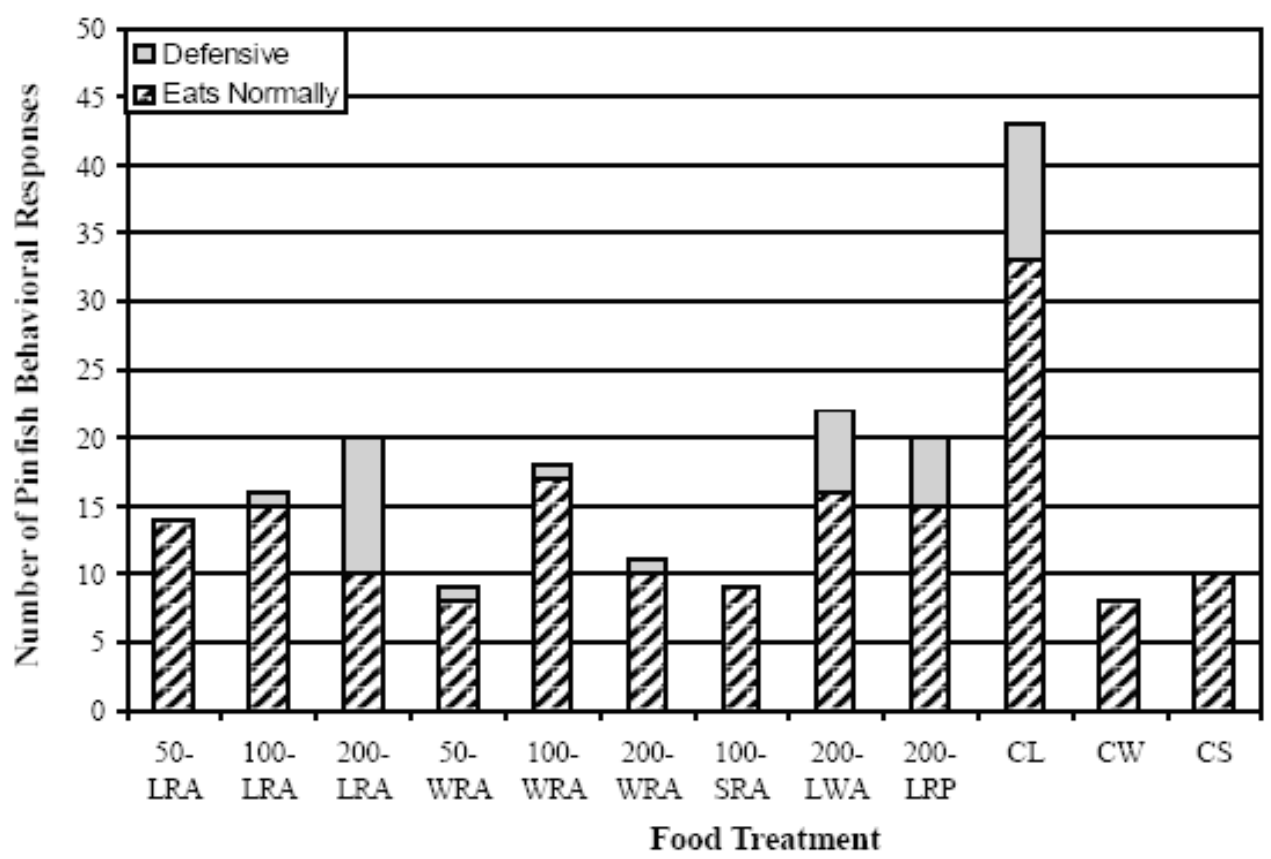

Fig. (3). Number of pinfish (Lagodon rhomboides) behavioral responses to food treatments. Numbers on the x-axis represent percent (e.g. 50 -LRA $=50 \%$ - Lipophilic (L) Red (R) Atlantic (A)) of the NVC of extract in treatment foods. Symbols are as follows: Lipophilic $=(\mathrm{L})$, water soluble $=(\mathrm{W})$, sclerite $=(\mathrm{S})$, and control $=(\mathrm{C})$, red $(\mathrm{R})$ and white $(\mathrm{W})$ Paragorgia arborea color morphologies, and Atlantic $(\mathrm{A})$ and Pacific (P) Ocean locations.

coral collected from the North Atlantic Ocean than those coral collected from the North Pacific Ocean. Further, when the $200 \%$ NVC lipophilic food treatment prepared from red $P$. arborea from the North Atlantic Ocean was compared to the same treatment for white $P$. arborea from the same region, the red coral produced significantly more defensive responses than the white coral.

\section{Fish Standard Length (SL)}

Fish standard length (SL) varied slightly by month over the duration of our two year experimental period, with the averages and $95 \%$ confidence intervals for SL: $51.0 \pm 9.4$ $\mathrm{mm}$ for September, $63.3 \pm 4.2 \mathrm{~mm}$ for October, $57.8 \pm 6.5$ $\mathrm{mm}$ for November, $57.7 \pm 3.1 \mathrm{~mm}$ for December, $64.6 \pm 3.2$ $\mathrm{mm}$ for February, and $36.8 \pm 8.5 \mathrm{~mm}$ for March. Overall, fish had an average SL of $56.2 \mathrm{~mm}(95 \%$ confidence interval 53.2 to $59.1 \mathrm{~mm}$ ). However, behavioral responses were not significantly different for pinfish of different standard lengths $(z=-0.86, p=0.387$, multinomial model, program $\mathrm{R})$.

\section{Sampling Day}

Pinfish behavioral responses did not vary on trial days two and three when compared with responses obtained on day one $(z=1.38, p=0.168$ for day $2 ; z=0.58, p=0.561$ for day 3 , multinomial model, program $\mathrm{R}$ ).

\section{DISCUSSION AND CONCLUSION}

The gorgonian Paragorgia arborea is bipolar in distribution, occurring in the southern hemispheres and in the north Atlantic and Pacific oceans, from the tip of Georges Bank, to Greenland, Iceland, and Norway [38, 39].
Despite a plethora of recent information describing the existence of various DSCs, their habitats and some of the associated flora and fauna [40], few studies have examined how DSCs exist free of fouling organisms, how they attract larvae for colonization of substrates, or what mechanism they use to deter predation. It is likely that DSCs likely possess as many or more secondary metabolites than tropical corals because of the harsh environments they appear to thrive within.

\section{Hypothesis 1: Paragorgia arborea from Various Geographic Regions will Elicit Different Anti-Predatory Responses in Fish}

We hypothesized that deep-sea $P$. arborea colonies from various geographic regions would elicit different behavioral responses to fish. Overall we found significant differences in only one treatment. The $200 \%$ NVC lipophilic food treatment with extract from red $P$. arborea colonies from the North Atlantic Ocean elicited a significantly different behavior in which fish rejected or completely avoided the food more often than the treatment associated with extracts from DSC collected from the North Pacific Ocean.

Although not well documented in the marine environment, patterns of intraspecific variation among species from different geographic terrestrial regions are well documented [41]. Significant differences of metabolite chemistry occurred in the coralline demosponge Astrosclera willeyana from two different locations in Australia [42]. Similarly, numerous research characterized differences in metabolite concentrations associated with algae [43-46]. However, fewer examples described intra-specific geographical metabolite differences in coral. Maida et al. [47] reported significant differences in flexibilide and sinulariolide metabolites of the soft coral Sinularia flexibilis among different sites at Lizard 
Island, Great Barrier Reef (Australia). Metabolite concentrations varied among the gorgonian coral Briareum asbestimum from different depths and geographical locations [48].

We propose three possible reasons why conspecifics living in different geographical regions may have varying concentrations of metabolites. First, such species may have differential selection pressures by predators [49]. Hay and Steinberg [50] suggested that species (e.g., coral and algae) subjected to high feeding pressures have larger concentrations of metabolites against herbivory than others in less pressured environments, which may be an evolutionary consequence of self preservation. Secondly, a species with a slower growth rate might generate a surplus of natural products [48]. Thirdly, similar species living in different geographical locations may be ingesting different prey items, leading to differences in the concentration and type of metabolite produced. D'Ambrosio et al. [11] and Stonik et al. [12] found that xeniolide diterpenes isolated from Paragorgia arborea differed in structure for colonies from different geographic regions, but were similar to compounds found in Dictyotales algae, indicating that Paragorgia may be ingesting dead brown algae matter as it sediments to the sea floor. Our study, however, does not allow one to distinguish between these three potential causes.

\section{Hypothesis 2: Fish will Display More Avoidance to Brighter Colored Paragorgia arborea Deep-Sea Coral Species}

Our second hypothesis in this study was that fish would display significantly more avoidance behavior to $P$. arborea colonies of brighter coloration (e.g., red). In this study we observed the red-colored $P$. arborea colonies $(100 \%$ and $200 \%$ treatments) caused significantly more defensive (e.g., avoidance) responses to predation than the white-colored colonies. Kelman et al. [49] observed similar variations in yellow- and grey-colored morphs of the Red Sea soft coral Parerythropodium fulvum fulvum occurring at different depths and locations, with lower concentration of metabolites in shallower coral than those at deeper depths. Such results seem counter intuitive because predation pressures are thought to be higher in species living in shallower depths than those living in deeper waters [51]. Higher predator avoidance occurred in grey-colored colonies vs. the brighter yellow-colored colonies, contradictory to our results [49]. Green et al. [52] who also studied the color morphs of $P$. fulvum fulvum in the Red Sea noted similar observations as Kelman et al. [49].

We question whether the differences in metabolite concentration between different color morphs might be related to male $v s$. female colonies. Might male $P$. arborea be red in color, and females white, or vice versa? This hypothesis appears unlikely, as only red colonies of $P$. arborea occurred in some geographic regions. Green et al. [52] reported differences in composition and concentration of secondary metabolites in male vs. female coral colonies, such that eggs released by female colonies had greatly elevated levels. Müller [53], on the other hand, reported the important role of a hydrocarbon olefin (1-but-1'enylcyclohepta-2,5-diene) as a brown algae sperm attractant.
The different phenotypic colors in DSCs may have an important role as gamete attractants and to their reproductive success. Hay [54] reported similar speculations in chemically rich taxa, where unpalatable larvae tended to be brightly colored while palatable larvae tended to be less colorful. Although relatively understudied, larval chemical defenses may provide important insights into the evolution of invertebrate life cycles, modes of dispersal, and ontogenetic development [54].

\section{Hypothesis 3: Fish will Display More Avoidance to Lipophilic DSC Compounds than to any other Treatment}

Our third hypothesis was that fish will avoid food treatments consisting of lipophilic compounds than to other treatments, i.e., those with water soluble or terpene compounds. The only treatment that produced significant results was the $200 \%$ NVC lipophilic food pellets. In general, this was not unexpected since lipophilic compounds are more effective behavioral deterrents against herbivores than, for example, polyphenolics [55]. However, polyphenolics are typically produced in much higher concentrations $[43,56,57]$. In $60 \%$ of the studies of avoidance of seaweeds by sea urchins differences in palatability of seaweeds to urchins was caused by lipophilic compounds [58]. The reason lipophilic extracts are avoided may be that they cause tissue necrosis [59]. Lipophilic extracts from the red alga Plocamium hametum, coated on plastic aquarium plants, caused tissue damage to nearby invertebrates while other plants without such extracts caused no harm [59].

The ecological relevance of our result is questionable since this concentration $(200 \%$, or twice the normal concentration) may not be found under natural conditions in these coral. However, intra-specific variance in metabolic production is only beginning to be investigated and such concentrations may exist [48, 50, 58, 60-63]. Different portions (i.e., top vs. middle vs. bottom of a colony) of an individual red $P$. arborea colony might vary in the composition and concentration of metabolites. Similarly, the composition and concentration of metabolites might vary seasonally because of differences in the local chemical composition of the seawater, particularly if the metabolites have their origins from ingested prey, and prey fields vary seasonally. We also noted that in our study of defensive mechanisms of DSC metabolites to fish predation, many corallivorous fish species have evolved adaptations that enable them to forage on corals. These may include biomechanical characteristics (i.e., jaw morphology) as well as physiological and biochemical characteristics that may enable them to digest corals and withstand their chemical defenses. Non-corallivorous species may lack such evolutionary adaptations; L. romboides naturally feeds on seagrasses and invertebrates and not coral as its primary food sources, and it is possible that the metabolites of $P$. arborea may have had limited effects. Seagrasses, like DSCs, however, similarly produce terpene and steroid metabolites [64-66] and therefore our question as to whether these metabolites affect behavior of fish was relevant; we suggest that future studies might include a wider variety of fish species and where possible, include deep-sea predators collected from the same habitat as the DSC. 


\section{Hypothesis 4: Sclerites of Paragorgia arborea Serve a Role in Predator Avoidance}

Our last hypothesis was that sclerites possessed by $P$. arborea might serve a role in predator avoidance. However, none of the pinfish responded defensively. This was surprising since sclerites associated with alcyonacean [30, 67] and gorgonian [68-70] shallow water corals are known to serve as mechanisms in anti-predator defense [69-73] in addition to providing many soft-bodied invertebrates skeletal support. Yet, not all of the available evidence corroborates the hypothesis that sclerites serve as defense against predation [74]. Lindquiest et al. [75] and [76], for example, reported that sclerites associated with ascidians and sponges were palatable. The length, shape, and density/concentration of sclerites may determine whether they are used to deter predation [77, 78]. In the gorgonian Briareum asbestinum, long sclerites were less palatable to predators than short sclerites [78]. In DSCs, sclerite morphology has not been examined with respect to predator avoidance.

This study provides one of the few direct tests of the hypothesis that secondary metabolites play a role in deep-sea coral anti-predation, although the presence and structure of some of these metabolites previously has been examined. We have also shown that calcitic sclerites have little to no role in anti-predation. In all but one treatment, predation was not strongly correlated with the concentration of the metabolites present, suggesting that the metabolites may have alternate functions such as reproduction. Clearly, more research is required to determine why coral populations from different geographical locations would produce different concentrations of chemical compounds. Additional research is also needed to determine how significant color variation is to gamete survival, coral reproduction and/or predation in the deep-sea corals.

\section{ABBREVIATIONS}

$\begin{array}{ll}\text { DSCs } & =\text { Deep-sea corals } \\ \text { DCM } & =\text { Dichloromethane } \\ \text { DI } & =\text { Deionized } \\ \mathrm{SL} & =\text { Water, fish standard length } \\ \mathrm{CH}_{3} \mathrm{OH} & =\text { Methanol } \\ \mathrm{NVC} & =\text { Natural volumetric concentration } \\ \mathrm{ROV} & =\text { Remotely operated vehicle } \\ \mathrm{Na}_{2} \mathrm{~S}_{2} \mathrm{O}_{3} & =\text { Sodium thiosulfate }\end{array}$

\section{ACKNOWLEDGEMENTS}

We thank Dr. E. Billiot for use of his laboratory and assistance with isolating chemical compounds, Dr. B. SterbaBoatwright for statistical advice, and Dr. J. Fox for use of seawater facilities. Drs. P. Etnoyer and R. Stone provided frozen and dried tissue samples collected from US locations. L.E. Diaz provided assistance with collecting fish. Dr. J. Sanchez provided advice and personal observations. We thank Drs. D. Scott, M. Risk, and E. Kenchington for samples collected from Canada. We are grateful to the Texas Research Development Fund for grants to Dr. K.B. Strychar.
Grants from the Office of Ocean Exploration provided funding to Dr. T.C. Shirley to collect specimens and observations.

\section{REFERENCES}

[1] Cairns SD, Bayer FMA. Generic revision and phylogenetic analysis of the Primnoidae (Cnidaria: Octocorallia). Smithsonian Contributions to Zoology No. 629. Smithsonian Institution Scholarly Press: Washington, D.C.; 2009.

[2] Heifetz J. Coral in Alaska: distribution, abundance, and species associations. Hydrobiology 2002; 471:19-28.

[3] Buhl-Mortensen L, Mortensen PB. Crustaceans associated with the deep-water gorgonian corals Paragorgia. arborea (L., 1758) and Primnoa resedaeformis (Gunn., 1763). J Nat Hist 2004; 38: 123347.

[4] Mortensen PB, Buhl-Mortensen L. Morphology and growth of the deep-water gorgonians Primnoa resedaeformis and Paragorgia arborea. Mar Biol 2005; 147: 775-88.

[5] Nedashkovskaya OI, Kim SB, Lysenko AM, Frolova GM, Mikhailov VV, Bae KS. Bizionia paragorgiae gen. nov., sp. nov., a novel member of the family Flavobacteriaceae isolated from the soft coral Paragorgia arborea. Int J Syst Evol Microbiol 2005; 55: 375-8.

[6] Roark EB, Guilderson TP, Dunbar RB, Ingram BL. Radiocarbonbased ages and growth rates of Hawaiian deep-sea corals. Mar Ecol Prog Ser 2006; 327: 1-14.

[7] Tendal OS. The North Atlantic distribution of the octocroal Paragorgia arborea (L., 1758) (Cnidaria: Anthozoa). Sarsia 1992; 77: 213-7.

[8] Sánchez JA. Systematics of the bubblegum corals (Cnidaria: Octocorallia: Paragorgiidae) with description of new species from New Zealand and the Eastern Pacific. Zootaxa 2005; 1014: 1-72.

[9] Bayer FM. Two new species of the gorgonacean genus Paragorgia (Coelenterata: Octocorallia). Prec Corals Octocoral Res 1993; 2: 140.

[10] Deichmann E. The Alcyonaria of the western part of the Atlantic Ocean. Mem Muse Comp Zool (Harvard) 1936; 53: 1-317.

[11] D'Ambrosio M, Guerriero A, Pietra F. Arboxeniolide-1, a new, naturally occurring xeniolide diterpenoid from the gorgonian Paragorgia arborea of the Crozet Is. (S. Indian Ocean). Z Naturforsch C Biosci 1984; 39: 1180-3.

[12] Stonik VA, Makar'eva TN, Dmitrenok AS. New diterpenoid of the xeniane series from the gorgonian Paragorgia arborea. Chem Nat Comp 1990; 26: 103-4.

[13] Rice T. Deep Ocean. Washington, Smithsonian Institution Press: D.C. 2000 ; p. 96.

[14] Rozadowsi HM. Fathoming the ocean: the discovery and exploration of the deep sea. Cambridge: M.A. The Belknap Press of Harvard University Press, 2005.

[15] Dattagupta S, Martin J, Liao S, Carney RS, Fisher CR. Deep-sea hydrocarbon seep gastropod Bathynerita naticoidea responds to cues from the habitat-providing mussel Bathymodiolus childressi. Mar Ecol 2007; 28: 193-8.

[16] Hendrickson JB. The molecules of nature: a survey of the biosynthesis and chemistry of natural products. New York: W. A. Benjamin, Inc. 1965.

[17] Newman AA. Chemistry of terpenes and terpenoids. New York: Academic Press 1972.

[18] Poza JJ, Fernández R, Reyes F, Rodríguez J, Jiménez C. Isolation, biological significance, synthesis, and cytotoxic evaluation of new natural parathiosteroids A-C and analogues from soft coral Paragorgia sp. J Org Chem 2008; 73: 7978-84.

[19] Ritson-Williams R, Paul VJ. Marine benthic invertebrates use multimodal cues for defense against reef fish. Mar Ecol Prog Ser 2007; 340: 29-39.

[20] Davies-Coleman MT, Beukes DR. Ten years of marine natural products research at Rhodes University. S Afr J Sci 2004; 100: 539-44.

[21] McClintock JB, Baker BJ. Chemical ecology in Antarctic seas: chemical interactions can lead to unusual arrangements between species. Am Sci 1998; 86: 254.

[22] Sokolowski A, Richard P, Fichet D, Radenac G, Guyot T. Application of trichloroacetic acid (TCA) to extraction of soft body for the determination of tissue $\mathrm{Cd}, \mathrm{Cu}, \mathrm{Pb}$, and $\mathrm{Zn}$ in the 
prosobranch Hydrobia ulvae (Pennant). Mar Pollut Bull 2003; 46: 1326-33.

[23] Lopanik N, Lindquist N, Targett N. Potent cytotoxins produced by a microbial symbiont protect host larvae from predation. Oecologia 2004; 139: 131-9.

[24] Kicklighter CE, Fisher CR, Hay ME. Chemical defense of hydrothermal vent and hydrocarbon seep organisms: a preliminary assessment using shallow-water consumers. Mar Ecol Prog Ser 2004; 275: 11-19.

[25] Pawlik JR, Chanas B, Toonen RJ, Fenical W. Defenses of Caribbean sponges against predatory reef fish. I. Chemical deterrency. Mar Ecol Prog Ser 1995; 127: 183-94.

[26] Pawlik JR, Fenical W. Chemical defense of Pterogorgia anceps, a Caribbean gorgonian coral. Mar Ecol Prog Ser 199; 87: 183-8.

[27] McEachran JD, Fechhelm JD. Fishes of the Gulf of Mexico, Scorpaeniformes to Tetraodontiformes. Austin, T.X.: University of Texas Press 2005, Vol. 2.

[28] McKee DA. Fishes of the Texas Laguna Madre. Texas: A\&M University Press, College Station 2008.

[29] Lindquist N, Hay ME. Can small rare prey be chemically defended? The case for marine larvae. Ecology 1996; 76: 1347-58.

[30] Puglisi MP, Paul VJ, Biggs J, Slattery M. Co-occurrence of chemical and structural defenses in the gorgonian corals of Guam. Mar Ecol Prog Ser 2002; 239: 105-14.

[31] Epifanio RA, Maia LF, Pawlik JR, Fenical W. Antipredatory secosterols from the octocoral Pseudoptero-gorgia americana. Mar Ecol Prog Ser 2007; 329: 307-10.

[32] Zumdahl SS, Zumdahl SA. Chemistry. $5^{\text {th }}$ ed. New York: Houghton Mifflin Company 2000.

[33] Kicklighter CE, Hay ME. Integrating prey defensive traits: contrasts of marine worms from temperate and tropical habitats. Ecol Monogr 2006; 76: 195-215.

[34] Lee PG, Meyers SP. Chemoattraction and feeding stimulation. In: D'Abramo LR, Conklin DE, Akiyama DM, Eds. Crustacean nutrition: advances in world aquaculture. Baton Rouge LA.: World Aquaculture Society 1997, Vol. 6. pp. 292-352.

[35] Spector P. Data manipulation with R. Berkeley, C.A.: Springer, 2008.

[36] Ott RL, Longnecker M. An introduction to statistical methods and data analysis, fifth ed. Duxbury, Pacific Grove, C.A.; 2001.

[37] Simonoff JS. Analyzing categorical data. New York: Springer 2003.

[38] Grasshoff M. Zur bipolaren verbreitung der oktocoralle Paragorgia arborea (Cnidaria: Anthozoa: Scleraxonia). Senckenberg Marit 1979; 11: 115-37.

[39] Hecker B. Variation in Megafaunal Assemblages on the Continental Margin South of New England. Deep-Sea Res 1990; 37: 37-57.

[40] Hatcher BG, Scheibling RE. What determine whether deepwater corals build reefs: Do shallow reef models apply? In: Willison JHM, Ed. Proceedings of the First International Symposium on Deep-Sea Corals, Ecology Action Centre and Nova Scotia Museum, Halifax, NS; 2001; pp. 6-18.

[41] Gershenzon J, Croteau R. Terpenoids. In: Rosenthal GA, Berenbaum MR, Eds. Herbivores: Their Interactions with Secondary Plant Metabolites, $2^{\text {nd }}$ ed. Orlando, Florida: Academic Press, 1991; pp. 165-219.

[42] Jahn T, König GM, Wright AD. Manzacidin D: an unprecedented secondary metabolite from the "living fossil" spong Astrosclera willeyana. Tetrahed Let 1997; 38: 3883-4.

[43] Paul VJ, Fenical W. Chemical defense in tropical green algae, order Caulerpales. Mar Ecol Prog Ser 1986; 34: 255-64.

[44] Paul VJ, Fenical W. Natural products chemistry and chemical defense in tropical marine algae of the Phylum Chlorophyta. In: Scheuer PJ, Ed. Bioorganic marine chemistry. Berlin: I. SpringerVerlag.; 1987; vol. I. pp. 1-37.

[45] Paul VJ, van Alstyne KL. Chemical defense and chemical variation in some tropical Pacific species of Halimeda (Halimedaceae; Chlorophyta). Coral Reefs 1988; 6: 263-70.

[46] Paul VJ, Littler MM, Littler DS, Fenical W. Evidence for chemical defense in the tropical green alga Caulerpa ashmeadii (Caulerpaceae: Chlorophyta): isolation of new bioactive sesquiterpenoids. J Chem Ecol 1987; 13: 1171-85.

[47] Maida M, Carroll AR, Coll JC. Variability of terpene content in the soft coral Sinularia flexibilis (Coelenterata: Octocorallia), and its ecological implications. J Chem Ecol 1993; 19: 2285-96.
[48] Harvell CD, Fenical W, Roussis V, Ruesink JL, Griggs CC, Greene $\mathrm{CH}$. Local and geographic variation in the defensive chemistry of a West Indian gorgonian coral (Briareum asbestinum). Mar Ecol Prog Ser 1993; 93: 165-73.

[49] Kelman D, Benayahu Y, Kashman Y. Chemical defence of the soft coral Parerythropodium fulvum fulvum (Forskål) in the Red Sea against generalist reef fish. J Exp Mar Biol Ecol 1999; 238: 127-37.

[50] Hay ME, Steinberg PD. The chemical ecology of plant-herbivore interactions in marine versus terrestrial communities. In: Rosenthal JA, Berenbaum MR, Eds. San Diego; Herbivores: their interaction with secondary metabolites, evolutional and biological processes, Academic Press 1992; pp. 371-413.

[51] Carpenter RC. Partitioning herbivory and its effects on coral reef algal communities. Ecol Monogr 1986; 56: 345-65.

[52] Green D, Kashman Y, Benayahu Y. Secondary metabolites of the yellow and gray morphs of the soft coral Parerythropodium fulvum fulvum: Comparative aspects. J Nat Prod 1992; 55: 1186-96.

[53] Müller DG. Quantitative evaluation of sexual chemotaxis in two marine brown algae. Z Pflanzenphys 1976; 80: 120-30.

[54] Hay ME. Marine chemical ecology: what's known and what's next? J Exp Mar Biol Ecol 1996; 200:103-4.

[55] Steinberg PD, Paul VJ. Fish feeding and chemical defenses of tropical brown algae in Western Australia. Mar Ecol Prog Ser 1990; 58:253-9.

[56] Ragan MA, Glomitza KW. Phlorotannins: brown algal polyphenols. Prog Phycol Res 1986; 4: 129-241.

[57] Hay ME, Fenical W. Chemical ecology and marine biodiversity: insights and products from the sea. Oceanography 1996; 9: 10-20.

[58] Bolser RC, Hay ME. Are tropical plants better defended? Palatability and defenses of temperate versus tropical seaweeds. Ecology 1996; 77: 2269-86.

[59] de Nys R, Co11 JC, Price IR. Chemically mediated interactions between the red alga Plocamium hamatum (Rodophyta) and the octocoral Sin\&aria cruciata (Alcyonacea). Mar Biol 1991; 108: 315-20.

[60] Cronin G, Hay ME. Within-plant variance in seaweed chemical defenses: Optimal defense theory versus the growth-differentiation balance hypothesis. Oecologia 1996a; 105: 361-8.

[61] Cronin G, Hay ME. Susceptibility to herbivores depends on recent history of both the plant and animal. Ecology 1996b; 77: 1531-43.

[62] Cronin G, Hay ME. Amphipod grazing and induction of seaweed chemical defenses. Ecology 1996c; 77: 2287-301.

[63] Cronin G, Hay ME. Effects of light and nutrient availability on the growth, secondary chemistry, and resistance to herbivory of two brown seaweeds. Oikos 1996d; 77: 93-106.

[64] Montgomery JLM, Targett T. The nutritional role of seagrass in the diet of the omnivorous pinfish Lagodon rhomboids (L.). J Exp Mar Biol Ecol 1992; 158: 37-57.

[65] Pergent G, Boudouresque C-F, Dumay O, Pergent-Martini C, Wyllie-Echeverria S. Competition between the invasive macrophyte Caulerpa taxifolia and the seagrass Posidonia oceanic: contrasting strategies. BMC Ecol 2008; 8: 1-13.

[66] Qi S-H, Zhang S, Qian P-Y, Wang B-G. Antifeedant, antibacterial, and antilarval compounds from the South China Sea seagrass Enhalus acoroides. Botan Mar 2008; 51: 441-7.

[67] van Alstyne KL, Wylie CR, Paul VJ, Meyer K. Antipredator defenses in tropical Pacific soft corals (Coelenterata: Alycyonacea). I. sclerites as defenses against generalist carnivorous fishes. Biol Bull 1992; 182: 231-40.

[68] Gerhart DJ, Rittschof D, Mayo SW. Chemical ecology and the search for marine antifoulants. J Chem Ecol 1988; 14: 1905-17.

[69] Harvell CD, Fenical W, Green CH. Chemical and structural defenses of Caribbean gorgonians (Pseudopterogorgia spp.). I. development of an in situ feeding assay. Mar Ecol Prog Ser 1988; 49: 287-94.

[70] van Alstyne KL, Paul VJ. Chemical and structural defenses in the sea fan Gorgonia venrulina: effects against generalist and specialist predators. Coral Reefs 1992; 1: 155-9.

[71] Harvell CD, Suchanec TH. Partial predation on tropical gorgonians by Cyphoma gibbosum. Mar Ecol Prog Ser 1987; 38: 37-44.

[72] Sammarco PW, Coll JC. Chemical adaptations in the Octocorallia: evolutionary considerations. Mar Ecol Prog Ser 1992; 88: 93-104.

[73] Harvell CD, Fenical W. Chemical and structural defenses of Caribbean gorgonians (Pseudopterogorgia spp.): intracolony localization of defense. Limnol Oceanogr 1989; 34: 382-9. 
[74] Clavico EEG, de Souza AT, da Gama BAP, Pereira RC. Antipredator defense and phenotypic plasticity of sclerites from Renilla muelleri, a tropical sea pansy. Biol Bull 2007; 213: 135-40.

[75] Lindquist NL, Hay ME, Fenical W. Chemical defense of ascidians and their conspicuous larvae. Ecol Monogr 1992; 62: 547-68.

[76] Chanas B, Pawlik JR. Defense of Caribbean sponges against predatory reef fish. I. Spicules, tissue toughness, and nutritional quality. Mar Ecol Prog Ser 1995; 127: 195-211.
[77] West JM. The dual role of sclerites in a gorgonian coral: conflicting functions of support and defense. Evol Ecol 1998; 12: 803-21.

[78] Koh LL, Goh NKC, Chou LM, Tan YW. Chemical and physical defenses of Singapore gorgonians (Octocorallia: Gorgonacea). J Exp Mar Biol Ecol 2000; 251: 103-15.

Received: May 06, 2010

Revised: June 13, 2010

Accepted: June 17, 2010

(C) Bright-Diaz et al.; Licensee Bentham Open.

This is an open access article licensed under the terms of the Creative Commons Attribution Non-Commercial License (http://creativecommons.org/licenses/by$\mathrm{nc} / 3.0 /$ ), which permits unrestricted, non-commercial use, distribution and reproduction in any medium, provided the work is properly cited. 